\title{
An Ecosystem-Based Job-Creation Engine Fuelled by Technology Entrepreneurs
}

\author{
Tony Bailetti and Sonia D. Bot
}

\author{
"Startups aren't everything when it comes to job growth." \\ They are the only thing.
}

Tim Kane

Economist, entrepreneur, and author

\begin{abstract}
Job creation is at the centre of the rationale provided by governments and publicly funded organizations for investing in services purported to support entrepreneurs to launch and grow technology startups. However, little is known about how to design and build the engines that convert these publicly funded services into jobs in a region. In this article, we argue that the architecture of a job-creation engine fuelled by technology entrepreneurs is important and that it should be made visible to the stakeholders of a regional venture system. The manner in which the components of a job-creation engine are organized and integrated determines the effectiveness and efficiency of the conversion of public funds into jobs. Making visible the architecture of a job-creation engine enables individuals and organizations to: i) better understand the link between the investment made to service technology entrepreneurs and systematic job creation; ii) utilize the regional venture system more effectively; and iii) set the performance benchmark for capability improvement and rapid adjustment to environmental changes. The experience gained from operating Lead To Win since 2009 is used to describe the architecture of a job-creation engine fuelled by technology entrepreneurs that operate in Canada's Capital Region. Lead To Win is an ecosystem designed to help a technology venture generate sufficient revenue to create six or more knowledge jobs in the region within three years of inception.
\end{abstract}

\section{Introduction}

We know that public funds are spent to deliver services to technology entrepreneurs. We also know that technology startups create jobs, many of which are high-paying jobs. What we do not know is what the different types of engines that convert publicly funded services into jobs looks like. If we do not know what a job-creation engine fuelled by technology entrepreneurs looks like, how can we improve its effectiveness and efficiency? Or, know its limits? Or, add new components? Or, adjust it to cope with environmental turbulence?

The objectives of this article are twofold: i) to highlight the importance of the architecture of an engine that converts public services delivered to technology entrepreneurs into jobs and ii) to describe the architecture of Lead To Win, a job-creation engine designed and operated using the ecosystem approach.
We argue that the visibility of the architecture of a jobcreation engine is important and that job-creation engines with good architectures are critical in regions where jobs have been lost. The architecture of a job-creation engine should be made visible to the stakeholders of the venture system, including taxpayers, technology entrepreneurs, investors, service providers, and government personnel. To match or exceed the jobs lost in a region, a robust job-creation engine is needed.

The article makes two contributions. First, it provides details on how to design and operate a job-creation engine using an ecosystem approach. To accomplish this, we share the experience gained from operating the Lead To Win job-creation engine in Canada's Capital Region since 2009. Although Lead To Win is used as an example of a job-creation engine, there is no intention to position it as the best model for regional job-creation engines. We share Lead To Win's architectural design 


\section{An Ecosystem-Based Job-Creation Engine Fuelled by Technology Entrepreneurs} Tony Bailetti and Sonia D. Bot

rules, components, processes, and governance so others can contribute to making them better and to encourage others to share their own architectures for job-creation engines. Second, the article acts as a white paper that can be used to improve the ecosystem that exists today for the purpose of launching and growing "born globals" - ventures that address global market opportunities from inception (Tanev, 2012; timreview.ca/article/532).

In this article, we identify publicly-funded services delivered to technology entrepreneurs, define what is meant by the architecture of a job-creation engine, describe the architecture of Lead To Win, and identify the challenges of changing components of a job-creation engine. The last section provides conclusions.

\section{Publicly Funded Services for Technology Entrepreneurs}

To create new knowledge jobs, public funds in many regions are being used to:

- provide entrepreneurs with subsidized space in prominent, multi-million-dollar buildings that house providers of public services, consultants, and commercial enterprises

- hire dozens of individuals to provide advice to entrepreneurs

- pay bureaucrats to select and fund technology startups deemed to be the "winners" of the future

- replicate what other regions have done to generate jobs

- operate incubators, accelerators, entrepreneurship centres, and hubs

- support venture capital funds that invest in technology firms

- invest in R\&D projects and prototype development

- provide large tax incentives to multinational firms that can act as anchors for the region's technology

- organize competitions and networking events that promote entrepreneurship

- attract rich immigrants with entrepreneurial experience

- link economic development organizations across regions
- deliver courses and workshops in entrepreneurship

- pay for travel and accommodations abroad

This list is not exhaustive. But, despite all these efforts, it is not clear how investments to help technology entrepreneurs are being converted into jobs. Although public funds are being used to pay for the delivery of a wide array of services to technology entrepreneurs, it is not clear what configurations of components are used to convert these services into jobs.

There have been few attempts at formally analyzing the efficacy of investor-centric technology startup accelerators that have emerged since 2005 (Miller and Bound, 2011; tinyurl.com/aoh3h6e). Private funds are used to operate these startup accelerators and they do not focus on job creation as an important outcome (Startup Genome, 2012; tinyurl.com/b3e477d).

\section{Architecture of the Lead To Win Job-Creation Engine}

Lead To Win (leadtowin.ca) is an ecosystem that delivers services to technology entrepreneurs for the purpose of creating knowledge jobs in Canada's Capital Region. With a population of 1.4 million, Canada's Capital Region is an official federal designation for the Canadian capital of Ottawa, Ontario, the neighbouring city of Gatineau, Quebec, and surrounding urban and rural communities. Employment in the high-technology sector has decreased significantly due to the bankruptcy of Nortel (tinyurl.com/24gm7a). Bailetti and Hudson (2009; timreview.ca/article/308) provide background information on Lead To Win and the region where it operates.

Today, Lead To Win is a job-creation engine fuelled by technology entrepreneurs. The engine is used to convert services to technology entrepreneurs into jobs in Canada's Capital Region.

The Lead To Win job-creation engine can be conceptualized as a collective of organizations and individuals that collaborate to support the launch and growth of technology ventures. Each venture is expected to create a minimum of six knowledge jobs in Canada's Capital Region within three years after its inception. The collective seeks to deliver outcomes that are not achievable by the organizations and individuals working on their own. The number and diversity of knowledge jobs and investment attracted to the region are this engine's key outcome indicators. 


\section{An Ecosystem-Based Job-Creation Engine Fuelled by Technology Entrepreneurs}

\section{Tony Bailetti and Sonia D. Bot}

A distinguishing feature of Lead To Win, relative to other ecosystems, is that it incorporates best practices grounded in sound academic principles and utilizes action-oriented metrics for decision making and tracking progress.

\section{Architectural design rules}

The architecture of Lead To Win is based on the following 10 design rules:

1. Each technology venture must commit to creating a minimum of six knowledge jobs within three years of inception.

2. An ecosystem approach is used to help entrepreneurs launch and grow successful technology ventures.

3. Stakeholders are anchored around a process-centric platform based on governance rules that guide the engagement between entrepreneurs and implementers as well as the stakeholders that support them.

4. Shared resources (e.g., a sales force, boards that track and guide ventures' progress, access to investors, workshops, opportunity review boards, back office support) and assets (e.g., educational resources, journal articles, software platforms) are developed on an ongoing basis.

5. Stakeholder engagement points are aligned with the ventures' needs for growth and the health of the ecosystem.

6. Compelling value propositions are developed for each stakeholder group that is able and willing to satisfy the needs of technology entrepreneurs and their ventures.

7. The cost structure to venture stakeholders must lead to ecosystem sustainability.

8. Indicators, endpoints, and parameters relevant to regional economic prosperity are used to assess how well the ecosystem is functioning.

9. Program services are provided only to technology entrepreneurs whose opportunities have been rated "green" by a Lead To Win Opportunity Review Board using a seven-dimension rating system.

10. Transparent ecosystem governance is provided through the Lead To Win Council.

\section{Components}

Technology entrepreneurs whose opportunities have been rated "green" by the Lead To Win Opportunity Review Board receive benefits (e.g., services) from program elements that are organized into five components. These components differ in terms of the value they add to creating jobs and the specialized knowledge required for delivering these services. Figure 1 identifies the five components used to organize the services delivered by Lead To Win to technology entrepreneurs.

Component 1 consists of renting space operated by incubators or accelerators located in various neighbourhoods. Space is then provided free of charge to technology entrepreneurs. Lead To Win does not own its own building.

Component 2 includes the following services to technology entrepreneurs: opportunity assessments, a six-day bootcamp, the Technology Innovation Management Lecture Series, workshops for entrepreneurs, and events delivered jointly with ecosystem member organizations.

Component 3 comprises services provided by five "desks", which are differentiated by their functional elements. A network of university-student interns and service providers delivers the services offered by each desk. An individual "desk prime" leads the operations of the desk and coordinates its activities with the leads of the other desks and the Lead To Win Council. There are five Lead To Win desks:

1. Invest Desk: educates, trains, and coaches startup founders regarding external investment and facilitates fundraising for companies with global opportunities that have matured sufficiently to be ready for external investment. It also assists founders to define and refine the list of target investors.

2. Develop Business Desk: educates, trains, monitors, coaches, and advises startup founders on how to grow their businesses using state-of-the-art business development, sales, and investment principles. It also assists startup founders in defining and refining a list of target business relationships and in the development of business pitches for partnership activities.

3. Sales Desk: educates, trains, monitors, and coaches startup founders on how to improve the success of their customer sales engagements and assists founders to: define and refine the list of prospect cus- 


\section{An Ecosystem-Based Job-Creation Engine Fuelled by Technology Entrepreneurs Tony Bailetti and Sonia D. Bot}

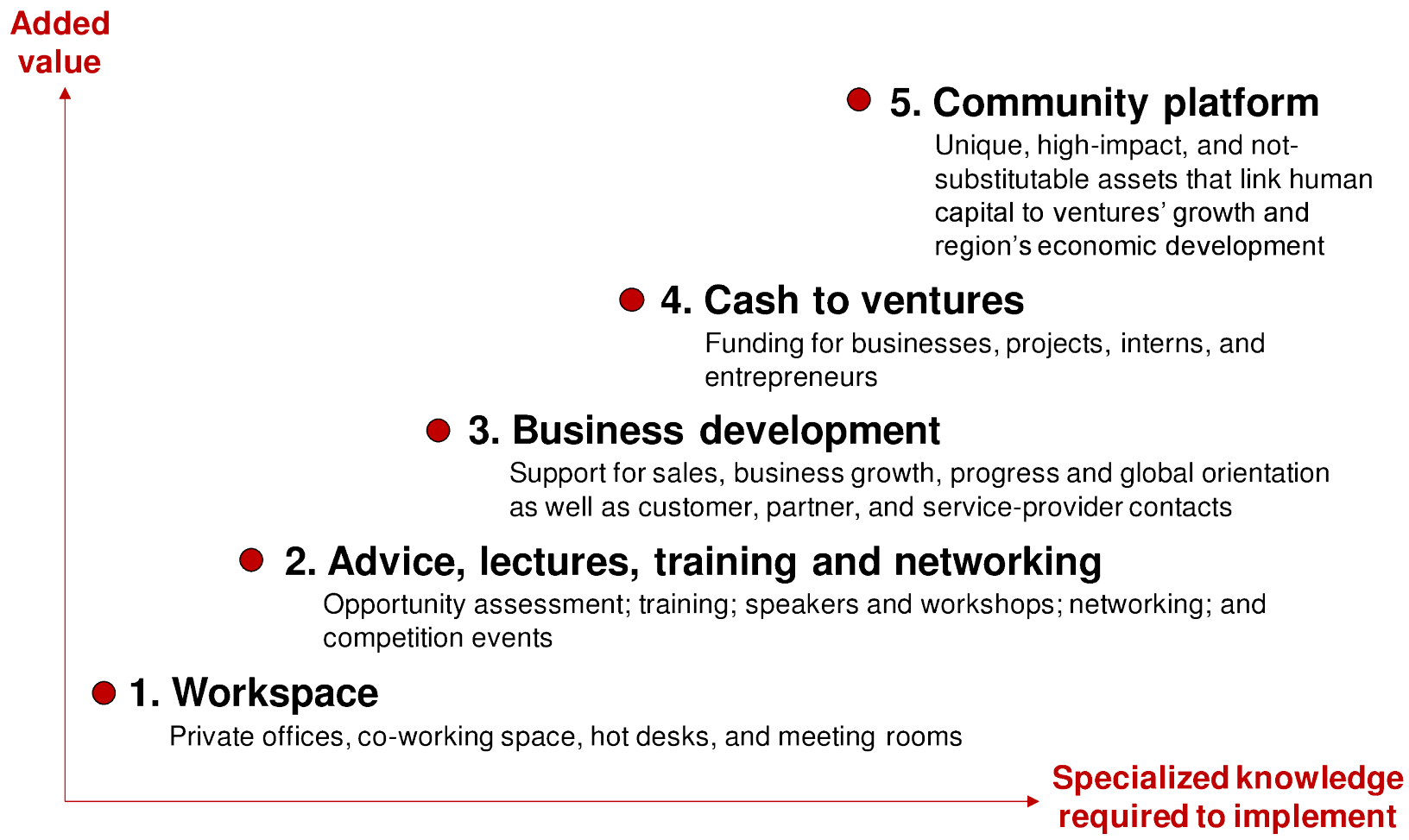

Figure 1. Five components of Lead To Win services delivered to technology entrepreneurs

tomer accounts, develop call scripts, make cold calls, actively engages in sales campaigns, form new customer relationships, and strengthen existing customer relationships. It also supports startup founders to close sales.

4. Progress Desk: manages board reviews that ensure companies meet growth milestones. It also maintains accurate data and reports on ventures' milestones, enforces criteria for maintaining "green" status, manages the process for removing nonperformers, and assists founders to meet milestones at each stage of the growth process.

5. Global Desk: educates, trains, and coaches founders and stakeholders on how to launch and grow ventures that are global upon inception, assists startup founders and stakeholders to develop and grow born globals (that is, ventures that are global from inception), works with all desks to define and develop tools to support founders of born globals and identify milestones relevant to born globals, and leads the transition from the current state to a state where all companies are born globals.
Component 4 comprises programs that deliver cash to entrepreneurs and their technology ventures. Currently these programs pay for: student interns working for a startup, living expenses of student entrepreneurs, and projects to launch born-global ventures.

Component 5 includes services derived from assets that are unique, high-impact, and not substitutable. These assets link human capital to ventures' growth and the region's economic development. Currently these assets include: Founders and Ventures, Mentors, Faculty and Reviewers Network, the TIM Review (timreview.ca), master-level theses and projects (carleton.ca/tim), the BigBlueButton web conferencing system (bigbluebutton.org), tools and processes, and the Research Centre for Technology Innovation.

Process platform

The Lead To Win ecosystem is anchored around a process platform that guides the engagement among ecosystem members throughout the venture-creation lifecycle. Members of the governance council ensure that the ecosystem as a whole operates effectively and that each venture delivers a minimum of six jobs three years after inception. 


\section{An Ecosystem-Based Job-Creation Engine Fuelled by Technology Entrepreneurs} Tony Bailetti and Sonia D. Bot

Figure 2 provides a view of a venture's stakeholders anchored around a process for venture creation that helps founders of technology startups move from the idea stage through the opportunity stage to the stage where their ventures can generate sustainable revenue to support six or more jobs. Venture stakeholders are organized into three groups: i) entrepreneurs and implementers (denoted as leaders), ii) stakeholders that support the entrepreneurs (denoted as feeders), and iii) members of the governance council. The "leaders and feeders" notation follows Feld (2012; tinyurl.com/a2s2vf3).

Entrepreneurs lead the creation of ventures. Therefore, they become leaders of the startup community. Implementers bring about and build the ventures' offers. Implementers include startup's founders, employees, board of directors, advisors, and consultants. Implementers have a financial stake in the venture such as payment for services rendered or equity stakes in the venture. Everyone else provides for the community.

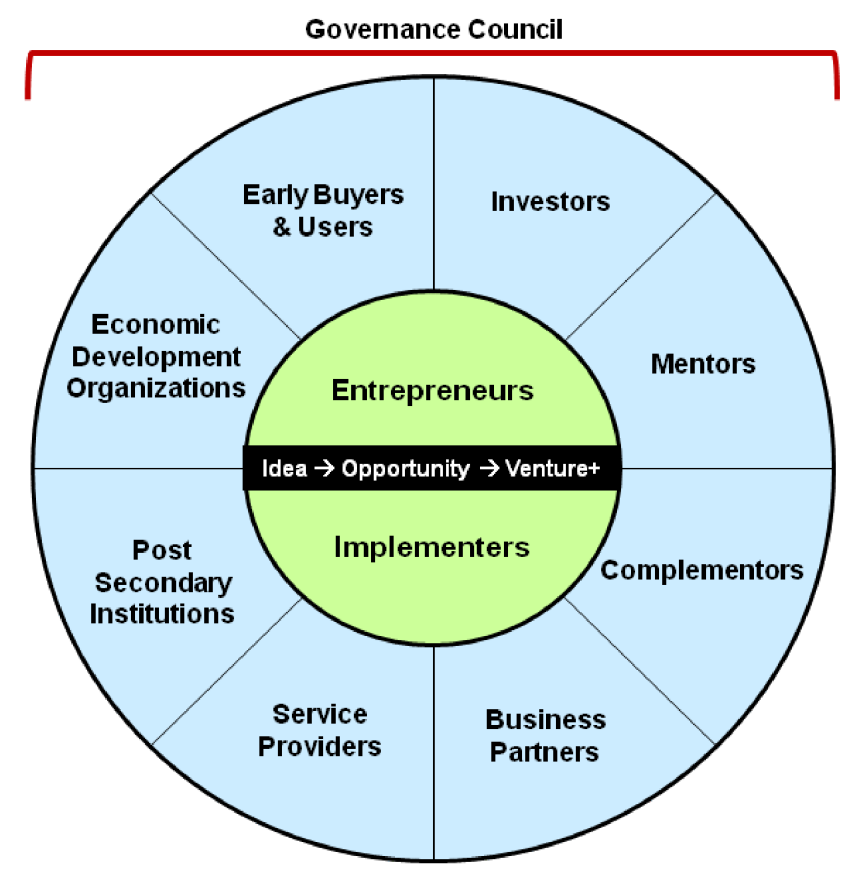

Figure 2. Venture stakeholders anchored around a process platform
The feeder stakeholders are defined as:

1. Mentors: provide domain knowledge or management expertise to entrepreneurs, based on experience. Mentors are volunteers; they have no financial stakes in the ventures they assist.

2. Post-secondary institutions: universities and colleges provide entrepreneurial knowledge and assets, reviewers for opportunity assessments, entrepreneurs, implementers, lab access, and research ready to exploit for commercial interest.

3. Service providers: professionals that provide services to the venture. Service providers include accountants, lawyers, and human resources providers.

4. Business partners: at the business-operations level, business partners are commercial entities that have some form of alliance with the newly forming venture. These stakeholders can include channel-tomarket partners, supply-chain partners, and manufacturing partners.

5. Complementors: businesses that directly sell products or services that complement the product or service of the new venture by adding value to mutual customers, thereby increasing the value to each complementor above the value achieved if operating as a standalone entity. For example, Microsoft (with its operating system) and McAfee (with its anti-virus software) are complementors.

6. Economic development organizations: public and not-for-profit groups that provide assistance to businesses, communities, and the organizations that support them.

7. Early buyers and users: in the diffusion-of-innovations timeline (tinyurl.com/27v6a3), this is the minority group of the addressable market that will try and buy the product or service.

8. Investors: provide dilutive capital funds to grow the venture. Vehicles include angel investors or groups, venture capital firms, and strategic investors (i.e., large, established firms). 


\title{
An Ecosystem-Based Job-Creation Engine Fuelled by Technology Entrepreneurs
}

\author{
Tony Bailetti and Sonia D. Bot
}

\section{Venture-Creation Process}

The venture-creation process anchors the business ecosystem. This section describes this process from two perspectives: i) the startup lifecycle and ii) ecosystem engagement points.

\section{Startup lifecycle}

Technology startups go through stages of development and maturation. Various models to conceptualize these stages exist. Some of the most popular ones include: i) the funding stages model (tinyurl.com/3x3vg3), ii) Steve Blank's customer development model (tinyurl.com/ b2eho2l), and the iii) the Marmer model for Internet startups (tinyurl.com/b3xpbnz).

Figure 3 illustrates the Lead To Win lifecycle stage model of a technology startup. Phase I focuses on evaluating the idea. Proponents pitch their ideas for an opportunity to a review board, where they are evaluated on criteria relating to customer value, competitive, and partner value. Once the criteria are met, the opportunity moves to Phase II, which provides training, feedback, and two tiers of opportunity reviews. An opportunity moves to Phase III once it meets the criteria for customer value, competitiveness, partner value, jobs generation, financial soundness, foundation for leveraging resources, and team. At Phase III, the entrepreneur has access to the full Lead To Win ecosystem. Phase III focuses on building out the minimum viable product (tinyurl.com/ yhstpma) and the minimum value organization to accel-

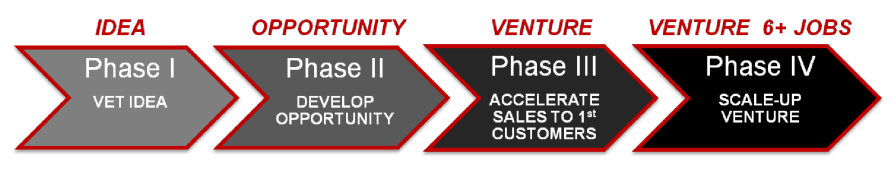

Figure 3. Lead To Win lifecycle stage model

erate sales to first customers. Phase IV focuses on scaling up the venture.

The startup lifecycle process is flexible to accommodate various types of startups, such as hardware and software products, enterprise products and services, Internet services, and consumer products and services.

Within this lifecycle stage model, various best practices for execution (e.g., business-model design, customer development, lean startup, agile development) are refined, supported, and tailored to the type of startup. As new practices and functions evolve, they are readily incorporated into the model.

Every business is different. However, in order to gain market credibility and succeed each business must get four things right: offer, customer, cash, and organization (Frei, 2008; tinyurl.com/32an5yl). Figure 4 shows the progression from inception where these four key elements are built up throughout the Lead To Win lifecycle stage model.

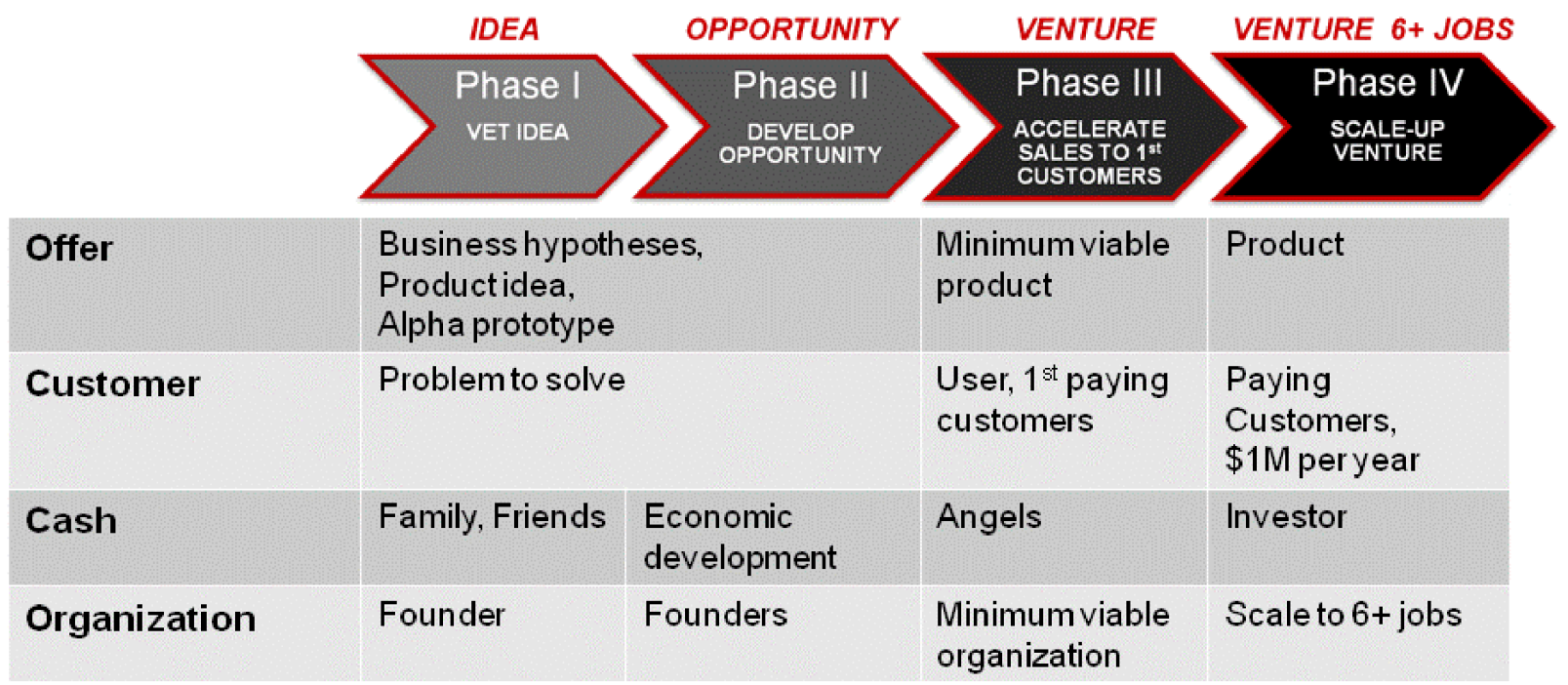

Figure 4. Building the four key elements of a startup through the Lead To Win lifecycle stage model 


\section{An Ecosystem-Based Job-Creation Engine Fuelled by Technology Entrepreneurs} Tony Bailetti and Sonia D. Bot

Ecosystem engagement points

As the startup progresses through its lifecycle, it engages with the Lead To Win ecosystem at various points appropriate to its stage of development, as shown in Figure 5.

The economic development organizations and the postsecondary institutions are available to the startup throughout each phase, though the nature of contribution is tailored to each stage. For example, the post-secondary institutions organize and conduct the opportunity reviews for Phases I and II, while drawing in members of the community to assist as reviewers. At Phase II, they lead the bootcamp training, which engages both academic and industry practitioners. Together with the economic development organizations, they secure early funding for the startups through government grants and endowments for Phases III and IV.
Regardless of phase, the post-secondary institutions develop assets such as journals and lecture series for practicing technology entrepreneurs, graduate degree programs, research on timely issues, technology-transfer support, tools and processes, and back-office support for the Lead To Win ecosystem.

There are two key inflection points for a startup in the Lead To Win ecosystem. The first is qualifying for the Lead To Win Phase II, which enables the startup to participate in the Lead To Win bootcamp training and opportunity development review and feedback, where pitches are formally presented to a review board at two points in the bootcamp. The second is qualifying to enter Phase III, which gives access to the full complement of the ecosystems resources. Once in Phase III, the engagement is continuous and always active, per the needs of the startup.

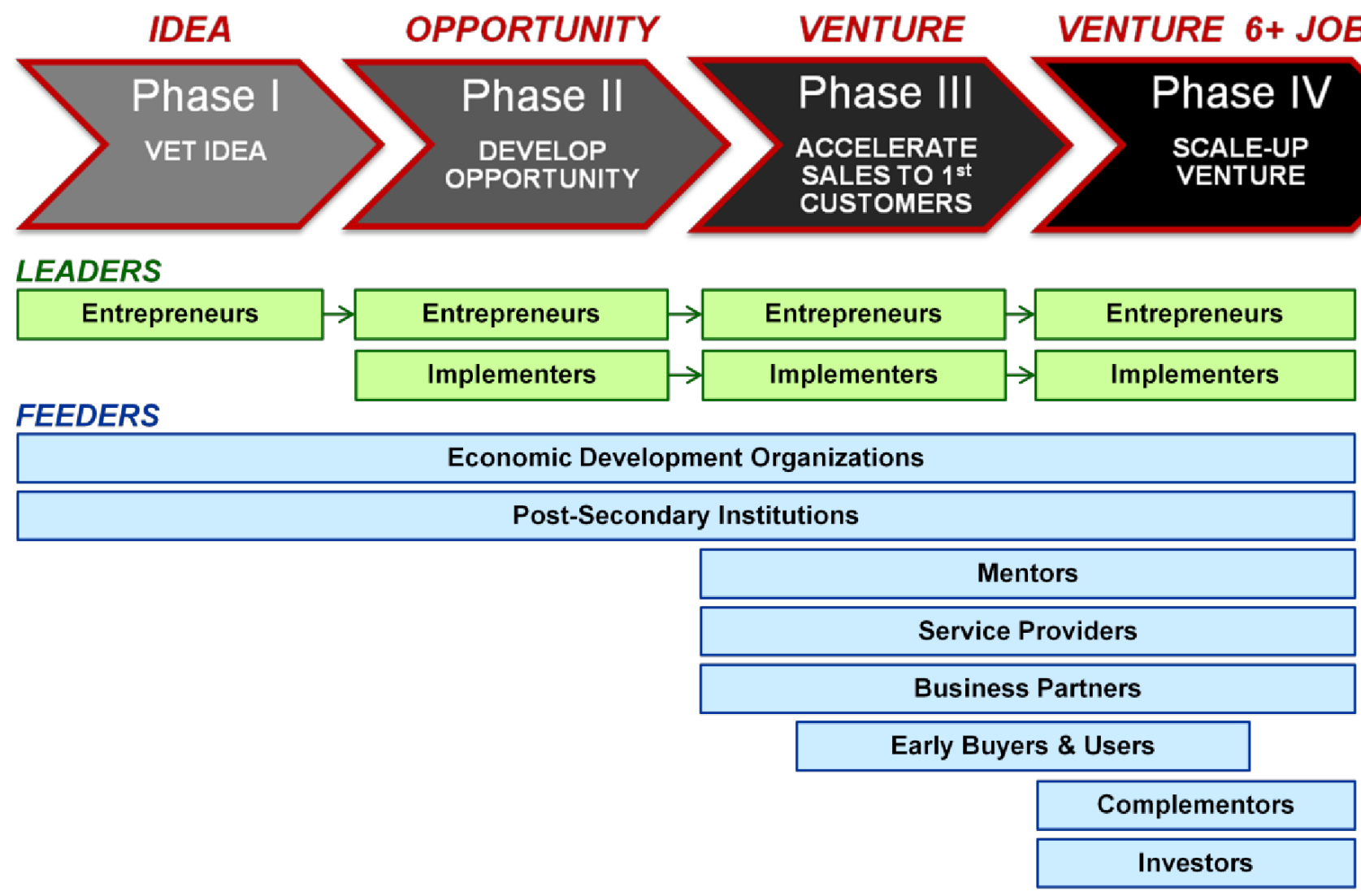

Figure 5. Engagement points with stakeholders in the Lead To Win ecosystem 


\section{An Ecosystem-Based Job-Creation Engine Fuelled by Technology Entrepreneurs Tony Bailetti and Sonia D. Bot}

\section{Governance}

Transparent governance of the startup ecosystem is essential in ensuring the ecosystem is operating effectively. Recently, the governance of the ecosystem has been transferred from the Technology Innovation Management Council to a 15-member Lead To Win Council. Both authors of this article are members of the Lead To Win Council.

The members of the Lead To Win Council are expected to be strategically focussed and act as a coordination and continuous improvement mechanisms. Tactics are the responsibility of the individuals and organizations delivering the services to technology entrepreneurs.

The governance model (Figure 6) will evolve as the ecosystem evolves. The orientation of the Lead To Win Council is data-driven, with predictive and outcome indicators for startup success, job creation, and regional prosperity. The governance board does not get involved in the management of the ventures; this is the responsibility of the ventures' own management teams.

\section{Notable Features}

The following features of the architecture of the Lead To Win job-creation engine are worth highlighting:

1. In return for free or heavily subsidized services, a technology entrepreneur is expected to grow their company's revenue to a level that can support a minimum of six knowledge jobs in the region. The focus of Lead To Win is to help technology entrepreneurs grow their companies revenue for the purpose of generating jobs in the region.

2. The Lead To Win stakeholder model does not have the "entrepreneur in residence" as a central role, as is typical with many other accelerators and incubators. The intent is to preserve autonomy for entrepreneurs and their top management teams.

3. The modularization of the ecosystem's components and elements enable rapid change.

4. Lead To Win provides services to technology entrepreneurs for the purpose of helping them navigate a process that helps them launch and grow companies in a region.

5. Desks help entrepreneurs "get things done" so they can advance their businesses, not just get advice about what needs to be done.

6. Feeder stakeholders are actively engaged in helping technology entrepreneurs launch and grow their businesses. It is a "pull system", where the leaders (i.e., entrepreneurs) declare when they are ready for the support of the feeders and the feeders respond quickly.

\section{GOVERNANCE of the ecosystem}

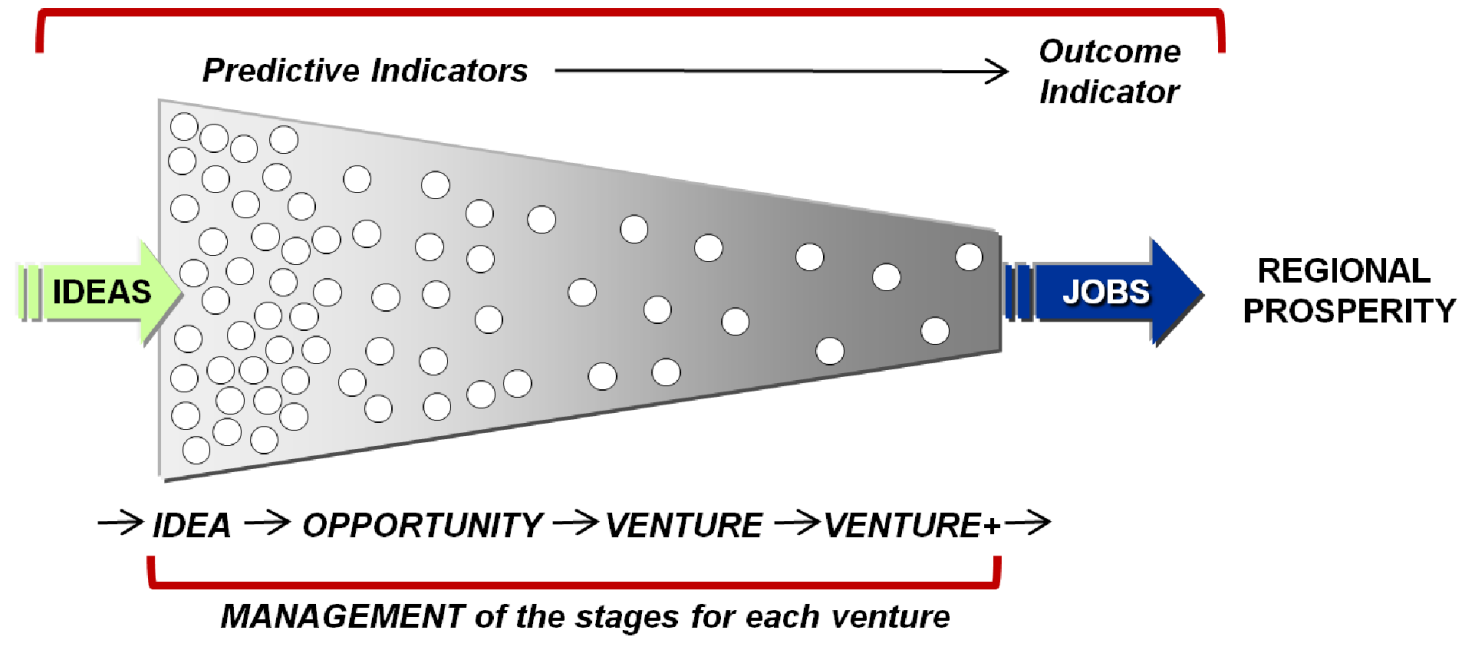

Figure 6. Governance of the venture ecosystem 


\section{An Ecosystem-Based Job-Creation Engine Fuelled by Technology Entrepreneurs} Tony Bailetti and Sonia D. Bot

\section{Adding New Capability to the Ecosystem: Born Global}

One of the strengths of this startup ecosystem is its responsiveness and resiliency in embracing changes in the environment, whether it is new technologies, management processes, or business models. The Lead To Win ecosystem is ready to take on the next challenge: incorporating the capability to launch and grow bornglobal ventures.

According to Tanev (2012; timreview.ca/article/532), born globals are firms designed to compete globally from their inception. They meet the needs of a global market - a market comprised of various markets that may include the company's domestic market. Most new technology firms first focus on the domestic market and then internationalize slowly; they become global by emergence, not by design. Born globals grow much faster than other firms. Being a "born global" is more about profiting from innovative business models than just selling to foreign customers.

A born-global technology firm can be readily distinguished from new, domestic-based small firms and conventionally internationalizing firms by examining the projects in which it invests. A born-global firm invests in projects to assemble and deploy specialized individuals and assets to derive significant competitive advantage from the use of resources and sales of outputs in multiple countries.

Lead To Win support for born globals in the ecosystem is a new differentiator relative to other job-creation engines that support entrepreneurs, one that is expected to significantly contribute to job creation and regional prosperity. Expanding the born-global capability in the ecosystem can be rolled out progressively. The post-secondary institutions are already engaged in bringing together effective practices and business models based on sound academic theory and empirical results.

The next step is to engage highly reputable private-sector industry practitioners to share their experience in growing and operating global businesses as part of a mentorship program. The mentorship program will focus exclusively on born globals; this is the "sweet-spot" for job growth and regional prosperity for technology startups.

The mentorship program will follow mentorship best practices and will establish effective processes for attracting, managing, and reporting work done by ment- ors. The mentorship program will: i) link the mentors with the venture founders; ii) train and support the mentors; iii) develop and disseminate mentoring best practices for launching and growing global businesses early and rapidly; and iv) maintain high quality and consistency of mentoring services to entrepreneurs. A simple process-management control system will be the underlying engine that monitors performance and raises flags when interventions are required. The intent is to build an adaptive system.

Over time, born-global support will pervade throughout all the stakeholder groups in the Lead To Win ecosystem.

\section{Conclusions}

The time has come for a formal analysis of the architectures of the engines designed to convert investments in public services delivered to technology entrepreneurs into jobs in a region. We encourage others to make visible the architectures of the engines they use to convert public investments to deliver services to technology entrepreneurs into regional jobs. Visibility of job creation architectures can help stakeholders better navigate the regional venture systems, compare them, and enhance them.

In this article, we make the Lead To Win engine visible because of our experience designing and operating it, and our desire to motivate others to make visible the distinguishing features of their own job-creation engines. 


\section{An Ecosystem-Based Job-Creation Engine Fuelled by Technology Entrepreneurs} Tony Bailetti and Sonia D. Bot

\begin{abstract}
About the Authors
Tony Bailetti is an Associate Professor in the Sprott School of Business and the Department of Systems and Computer Engineering at Carleton University, Ottawa, Canada. Professor Bailetti is the Director of Carleton University's Technology Innovation Management (TIM; carleton.ca/tim) program. His research, teaching, and community contributions support technology entrepreneurship, regional economic development, and international co-innovation.
\end{abstract}

Sonia Bot is an entrepreneurial-minded leader/executive and strategic thinker with extensive experience in technology innovation and global business management. She specializes in new venture creation, product management and delivery, business transformation and strategy, and leading organizational change. She is an accomplished industry presenter, author of numerous peer-reviewed published articles, and industry executive member of the Technology Entrepreneurship \& Commercialization Council at Carleton University. Ms. Bot currently partners with executives and entrepreneurs of small-medium enterprises and large entrepreneurial companies to assist in building, growing, and transforming new ventures and to solve wicked business problems. Her prior work experience includes Research In Motion / BlackBerry, Nortel, Bell-Northern Research, IBM, and TransCanada Pipelines. She holds degrees in Computer Science with Systems Design / Electrical Engineering (BMath) from the University of Waterloo and Biomedical Engineering (MASc) from the University of Toronto, and she is a certified Lean Six Sigma Master Black Belt. In November 2012, Ms. Bot received the honour of "Innovators \& Entrepreneurs" by the Institute of Biomaterials and Biomedical Engineering at the University of Toronto.

Citation: Bailetti, T. and S.D. Bot. 2013. An Ecosystem-

Based Job-Creation Engine Fuelled by Technology

Entrepreneurs. Technology Innovation Management

Review. February 2013: 31-40. 